temperament, a Pooh Bah by habit and a mandarin by instinct. Over nearly half a century, he was a powerful influence on several aspects of British public life, but mostly behind the scenes. Only in the past two decades (he was 88 when he died last week) has he spoken out in public, and in the liberal persuasion, on matters such as disarmament and Britain's policy on nuclear weapons, matters that occupied a great deal of his professional life in government. One of his last articles appeared earlier this year in Nature (361, 392; 4 February 1993) but the British government has not yet deigned to answer the awkward questions he raised in it.

Solly, Jewish and proud of it, and South A frican by origin, was an iconoclast in the limited sense that he saw it as his duty within the government and outside to tell people, officials and politicians when he considered that they were wrong. (But in the 1930s, while a teacher of anatomy at the University of Birmingham and investigating hormonal influences in reproduction, he had already been reproved for obscenity by the Archbishop of Canterbury - the executive head of the Anglican Church - over his first book, The Social Life of Monkeys and Apes.) His continued scepticism about Edward Teller's various proposals for innovation in nuclear weaponry and strategy became a legend; Teller was a friend he never made. But Zuckerman had a knack, a blend of humour and guile, that allowed him to tell his political masters they were mistaken without giving permanent offence. It was in that spirit that he persuaded Lord Mountbatten in the early $1960 \mathrm{~s}$ to take Pugwash seriously. On another occasion, he dissuaded Mountbatten from listening to a hare-brained proposal for a military take-over of the government.

Zuckerman was not an institutional iconoclast, but sometimes the opposite. His appointment in 1955 as Secretary of the Zoological Society of London, for example, was marked by his affection for the zoo, but also by ructions as he fought the old guard for his sensible proposals for change. (Recent events have sadly shown that they were not radical enough; Zuckerman's regret a few weeks ago was that he was not still in charge.) His capacity for doing several jobs, and simultaneously, seems to have been formed during this period; he was essentially full-time executive of the London Zoo and its appurtenances while moving from the Ministry of Defence to the Cabinet Office as the most senior and confidential adviser in sight, whence the reference to Pooh Bah.

Zuckerman was a mandarin (the British name for the head of a government department) in the antique Chinese sense; he conveyed the sense of having no power personally, but that there was a powerful emperor over his shoulder. That, of course, is a recipe for survival, but there is no doubt that Zuckerman enjoyed the influence this gave him, outside government as within. He was a great manipulator. Even so, it is a pity that he did not accept the challenge offered by Harold Wilson, 1964's new Prime Minister, of a post in the Foreign Office with responsibility for disarmament. His most fitting memorial would be that his friends should now press for an answer to the awkward questions on nuclear policy the British government has not yet answered.

\section{Horse-racing hoax}

The British, once a proud nation, have now lost even the
trick of organizing horse races, preferring hoaxes instead.

ONCE upon a time, the British used to boast of the battles they had won - Agincourt, Trafalgar and Waterloo (with less justice), for example. Then they boasted about technological innovations - steam engines, railway locomotives, steam turbines and so on. Latterly, they have been reduced to boasting of the spectacles they organize - the Highland Games (in Scotland in the summer), the Oxbridge boat race on the Thames and the horse race called the Grand National, which should have taken place last Saturday.

As is widely known, the race never happened. Instead, the organizers staged a hoax on the 39 horses and their jockeys, together with their trainers, owners and other hangers-on, the few tens of thousands of people waiting in the rain at Aintree (near Liverpool), those who had wagered $£ 75$ million on the outcome of the race in Britain alone and the score of broadcasting organizations elsewhere that had bought the right to show the event on television. Is it possible that the organizers had misread the calendar, believing that Saturday was the first of April, not the third?

The centrepiece of the hoax was a mechanical device a traditional way of arranging when horses in a race should begin to run. At most racetracks, horses are put in separate boxes which all open at the front when the race begins. Not so at the Grand National, where the horses are assembled behind a fibre rope (called a tape) some 70 metres long, whose ends are hoisted when the race is signalled to begin.

The technology of the starting mechanism is deceptively simple. Like any rope suspended from its ends, the Aintree tape must be disposed in catenary form. To allow the horses and their appended jockeys through, all points of the tape must rise by about 1 metre in the time it takes a horse to travel about the same distance from rest, perhaps much less than 0.1 seconds. Whether this will happen will be a function of the wave velocity along the tape, whose mass per unit length will have been increased, and wave velocity reduced, by the drenching rain last Saturday. On the first false start, the tape caught round some horses' necks. On the second, some jockeys were similarly incommoded.

The traditional technology for recalling horses after a false start is equally sophisticated: the official at the starting line waves a red flag if a start is false, and then a second official 200 metres down the track waves another. (Jockeys do not often look backwards at the beginning of a race.) Those who believe that klaxon horns or traffic lights (as used elsewhere), would more securely give warnings overlook the long tradition of the British flagman, one of whom by law carried a red flag before the early railway locomotives and then the first motorcars. Aintree says puckishly that this arrangement is reliable because it depends on people's judgement, but it is also a hoaxer's charter. On Saturday, the device did not work the second time. It remains to be told who played the hoax, and why. No other explanation is charitable. 